THE HOSTAGE BRAIII

\title{
The Hostage Brain
}

\section{By Bruce S. MCEWEN \& HaRold M. SCHMECK, JR. The Rockefeller University Press 1994 $\$ 19.95$}

\section{REviEWEd By ChaRLeS JeNNINGS}

Despite its enormous implications, brain research has yet to catch the public imagination in the way that, for example, astronomy has done. The Hostage Brain represents an attempt to redress the balance, by providing a popular account of the human brain and, in particular, the many ways it can go wrong. It is a laudable aim, and given the authors' credentials (one is a professor at Rockefeller University, the other is a former science correspondent for the New York Times), we might have anticipated a lively and illuminating read. Unfortunately, this book falls far short of such expectations.

The title derives from the authors' view that the human brain, and therefore the mind, is a "hostage" to its own physical nature, with all the limitations and vulnerabilities that this entails. There is no attempt to summarize how the brain works, or how it is constructed; rather, the "hostage" metaphore is explored through a series of examples and anecdotes that illustrate the diverse physical influences that bear upon the brain and the effects, good and bad, that they produce. Diet, hormones, stress, biological clocks, strokes, schizophrenia, genetic diseases, prions, Alzheimer's disease and ageing are among the topics covered; they are treated for the most part in an accurate and balanced manner, and there are a number of good stories. Among the best are those that illustrate the gap between science and public policy, such as the grim farce of the Louisiana prosecutors who attempted to have a murderous schizophrenic medicated so that he could be judged sane enough to be executed; in fact he was sane enough to refuse the treatment.

But despite such diversions, and despite the authors' efforts to make the book accessible, I did not find it an easy read. One problem is the lack of overall structure; it would probably have been useful to start with a summary of how genes, cells and synapses work, but the authors seem afraid to give their readers too much didactic material lest they lose interest. (They more or less admit this when they ask, of the enzyme that is deficient in Lesch-Nyhan syndrome, "how can anything with so many syllables be important in an age of shrinking attention spans?") The result is that the chapters do not build upon each other, and the book as a whole lacks a sense of continuity and direction. The authors have adopted an irritating tabloid style that many readers will find condescending, and which descends rather frequently to the level of breakfast TV commentary; to cite one example among many, on the subject of violent antiabortion protests, the authors write: "Such acts have added another, and frightening, dimension to the concept of the hostage brain. On the other hand, perhaps it was one of the original dimensions. Since the dawn of history, some human brains have taken countless others hostage by playing on ignorance, fear, greed, and all kinds of fanaticism. Such hostage-taking is the dark side of human imagination." Maybe so, but did we really need neuroscience to tell us this?

The tabloid influence is most obvious in the illustrations, many of which are vivid to the point of perversity. Brightly-coloured molecules drift across the pages like party balloons, a group of castrated cockerels glare angrily at the reader, a soldier with a striking resemblance to Saddam Hussein contemplates his own viscera. One of the more striking is the "fruit salad" nerve terminal on page 218 , in which vesicles are (unintentionally?) depicted as bowls of cherries and mitochondria as slices of orange. Some of this is merely distracting, but there are also several inexcusable errors: the depiction of protein synthesis, for instance, completely misrepresents the triplet code mechanism, and in one illustration of a synapse the neurotransmitter molecules, rather than binding to their receptors, pass right through and into the postsynaptic cytoplasm.

I assume that the intended readers are intelligent lay people, the sort of people who read the New York Times science pages and want to know more. Indeed they need to be informed; it has been estimated that brain-related illnesses cost the USA alone more than $\$ 300$ million each year, while the economic and social costs of drug addiction and its associated crime are far higher. Enlightened self-interest dictates that neuroscientists should draw these facts to the attention of the public, and explain to them what they are getting in exchange for their investment in brain research. Popular books are important if the tax dollars are to continue to flow, and The Hostage Brain may be seen as another attempt to stoke the fires of public interest.

But the book never really gets to grips with the most important promise that neuroscience offers, that of a deeper understanding of human nature. Most lay people may never want or need to know about the detailed workings of their frontal lobes, but they will at least need to think about the implications of such knowledge. A society of the future that understands the interplay of genes and experience in shaping our personalities, and the neural basis of such matters as decision-making, consciousness and free will (or the illusion thereof) will necessarily be different from our own, and will have different attitudes towards education, crime, personal responsibility and perhaps even religion. Neuroscience research is leading us slowly but steadily towards these questions, and the public will eventually have to confront them too. These are difficult themes, and it is perhaps understandable that McEwen and Schmeck have not really tried to tackle them. It is nevertheless the most serious limitation of their book, and will remain the biggest challenge for future writers on the subject.

Assistant Editor, Biology, Nature 1234 National Press Building Washington, DC 20045, USA 